\title{
Identification on the Excellence Value of Primary School in Malang
}

\author{
Endang Poerwanti \\ University of Muhammadiyah Malang \\ endangpoer@yahoo.com
}

\begin{abstract}
The research aims at identify the values of excellence on elementary schools in Malang based on the theoretical concepts, the formal legislation perspectives, and on the perception of stakeholders. The research was done by employing a descriptive qualitative design. The data collection was conducted by Focus Group Discussion, interview, questionnaire, and documentation. Then, the data were analyzed quantitatively and qualitatively. The results of the research indicate that: (1) formal school excellence is shown by the achievement of National Education Standards, (2) as far as the school teachers and principals are concerned, the school excellence can also be seen from the quality of human resources and vivid work program, and (3) the parents stated that an excellence school relies on its good student services, discipline, complete learning facilities, and the varieties of extracurricular program.
\end{abstract}

Keywords: excellence value, elementary schools

\section{INTRODUCTION}

Excellent school or excellently by the society, is a qualified school that became the reference for other schools. Excellent School or often referred to as an effective school [3]-[4]-[11]. Excellent School can be interpreted as a qualified school defined in education realm, the category of excellence implied expectations of competencies that owned by graduated students, whether the expectations of students, parents, and society [5]-[6][9].

Excellence, essentially felt by students, is how far schools can optimize their potential through individualized services in learning, which the results can be seen on graduates competency qualities in intellectual, moral, and skills abilities [2]-[10]-[14] that useful for students to continue their education and social life.

The benchmark for the effectiveness of the national education development implementation injunction can be seen from the quality education implementation indicators established byBNSP, which is reflected in the National Education Standard (SNP) with definite quantitative indicators [12]-[13]. The reality is, there are elementary schools that have been excellent although only three years established and there is no evidence of graduates quality yet, so "what schools are considered excellence by stakeholders".
Although the criteria and standards that apply in each school is not that definite, the Excellent School title is determined by the quality of education compared to education or educational institution in general. [1]-[7]-[15] School quality can also be seen from the developed excellent programs and the quality of cultures at school, which make it "distinctive" [2]-[8]-[17]. School culture is such set of values and norms that become the specialty in building and developing a unique trust and habit for its member to describe the commitment in togetherness. [16][18].

This research aims to identify the excellence value in Malang Elementary School based on theoretical concepts, formal legislation perspectives, and stakeholder perceptions.

\section{METHOD}

This research is a descriptive research that used quantitative method, combination of qualitative paradigm and quantitative data to clarify qualitative exposure.

Research location determinates purposively by choosing region according to research purpose that is Malang city. Based on the consideration of the education office and reckoning schools' quality, the distribution of location and the schools status (State and Private), it determinates 10 Excellent Primary Schools.

Field data accumulation involves principal, teacher, administrative staffs, students, and parents. Data accumulation using 5 (five) methods used simultaneously the FGD, in-depth interviews, observation, questionnaires, and documentation.

Exposure data as research result is the concept of Excellent School theoretically, juridical and Excellent School in stakeholder's perspective. Generally, the data is in the form of qualitative data, while some data in the form of numbers used to complement and describe the qualitative data.

\section{RESULT}

\section{Excellent Schools in Theoretical Studies.}

An Excellent school or Effective School is a school built by all school members. In theoretical concepts, Excellent Schools are always associated with qualified schools or effective schools [3]-[4]-[11]. Effective school measurement conceptualized from 9 indicators: (1) School has obvious vision and mission, (2) professional Principal, (3) professional teacher, (4) wide and balanced curriculum, (5) conducive school environment, (6) student-friendly, (7) 
strong management, (8) meaningful student achievement, and (9) high community involvement.

This theoretical concept is verified with the field data. This effective school indicator is theoretically translated into 67 descriptors and then scores 1-3 according to the fixed criteria, so the maximum effective school score result is 201. Observations and interviews with principals conducted in 10 sample schools show results; five schools showed very excellent scores with a range of values between 179-196, and the other five schools were in excellent classification in the 161-169 score range. This indicates that the Excellent Primary School in Malang is included as effective schools.

\section{Excellent School in Formal Juridical.}

Excellent School in the perspective of the Ministry of Education and Culture is schools that achieve excellence in the output of education. So that, it is viewed from formal measurement and criteria measured from the achievement of eight SNP Standards. National standards of education are the minimum criteria of the education system applicable throughout the jurisdiction of the Republic of Indonesia consisting of;

1. The competency standard of the graduates is qualification of graduate ability which includes attitude, knowledge, and skill.

2. Content standard is the scope of material and the level of competence, minimum in form of criteria of graduate competence.

3. Standard processes relating to the learning implementation to achieve graduate competency standards.

4. Standards of educators and educational personnel are the criteria of pre-service education, physical fitness, and education in service.

5. The standard of facilities and infrastructures are standards relating to the criteria of study space, sports venues, worship places, libraries, laboratories, workshops, and other learning resources to support the learning process.

6. Management standards are standards relating to the planning, implementation, and supervision of the educational process, in order to achieve the efficiency and effectiveness.

7. The standard of financing is the standard that regulates the component and the amount unit education cost applicable for one year.

8. Education Evaluation standard consists of: assessment of learning outcomes by teacher, assessment by school, and by the government.

In the implementation of the SNP, it has a function as the base of planning, implementation and supervisory mechanisms in order to realize national education quality. In relation to School Based Management, which has been promoted since 2002, building quality schools can be done by optimizing the three pillars, they are (1) principal management implementation, (2) active and enjoyable active learning by teachers, and (3) optimization of community participation, especially parents.

\section{Excellent Primary School in Malang}

The fact, there are schools that excellently acknowledged by community with a variety of perspectives of excellence based on community interpretation. It is apparent that there are schools that are not normally known for their outputs because they do not have any graduates yet, but have been excellent. This matter can be seen from the public interest to commit their children to the school.

FGD with school principals resulted that excellent schools should be able to accept students without rigorous selection, then maximize the process in school with various creative and meaningful learning experiences, with regard individual student differences and able to optimize their development. In this case, teachers competency as learning managers become focal point, not only the mastery of the subject matter, but also the ability to understand the learners, the various teaching strategies, media use, deviant behavior on the students handling.

In school managing, parents' satisfaction becomes very important. Excellent service to students will affect the satisfaction of parents. Parental satisfaction will support the success of programs launched to support and provide various assistance for the program success. This can be done through the preparation of clear and overt programs and activities, both for in-class activities, extracurricular activities, and enrichment activities. Therefore, it is necessary to deliver the goals and targets of the program, the overtones of the supporting facilities construct, as well as the implementation and consequent in carrying out in accordance with the planning.

Teacher states that the main one is comfort and job satisfaction. The beingness(?) of a clear job description and appreciation of performance will build commitment and responsibility for each teacher. Despite the accepting of different individuals, there is still frequent internal conflict among teachers. In this case the responsibilities of the principal to implement personnel management build the commitment to advance the school. School has also proved that it has provided an excellent service to students, which is evidenced in every year of schools are always flooded with registries. Of the 10 schools that sampled, seven schools did not conduct the selection. On the average, school received three classes with the number of 30-32 students. The latest SPM applies that the numbers of students in the primary school at maximum is 28 , then some schools receive 4 parallel classes. Some schools conduct enrolment tests but not to determine whether or not a student get received, but it is used as a placement test in order to determine students' early skills, as the first step of providing learning services that meet their abilities.

There are several ways to build and motivate parents and community participation for the development and improvement of school quality, namely (1) involving the community in various programs and social activities in schools, such as social service, separation, and so forth; (2) identify people who are able to influence the community, to be involved in specific activities such as resource persons and so on; and (3) choosing the right time to involve the community in accordance with the conditions and 
development of society. To reach quality, school should be able to make plans and agreements between the school and the stakeholders, each school must have the spirit, values, belief, and prevailing. School as a room for the formation and growth of students' characters, so that the atmosphere and condition of the school must be comfortable, clean, neat, and safe. The atmosphere and conditions are the task and responsibility of all components in the school environment, as value that is upheld and adhered to.

By formal regulation, the quality of the school is determined by the achievement of the SNP and Minimum Service Standards(SPM), the achievement of the SNP is done periodically by identifying the fulfillment of the SNP, then the result of the identification of the real condition compared to the SNP standard, that is used to make the plan of school programs. From the explanations, it can be identified that the characteristics of Excellence Primary School in Malang are;

1) Schools can provide optimal service to all children with different potency, talents of interest, and learning needs.

2) Schools are able to optimize the potential of students through learning and extra-curricular activities, for self-actualization and improve self-esteem.

3) Schools are capable of achieving a culture of quality and cultural achievement through the development of school culture.

4) Schools are able to build religious, independent, and responsible character, respecting diversity, and the spirit of nationalism.

5) Schools are able to optimize existing resources effectively and efficiently.

6) Schools are able to establish communication with parents and develop extensive networking, and

7) Schools are responsive to change.

\section{CONCLUSION}

1) Excellence school is theoretically equated to an effective school concept, which is reliable to the SBM.

2) The quality of formal excellence is the level of achievement of SNP and SPM. The gap between the real conditions and ideal conditions is used for the preparation of school programs.

3) The teacher is the spearhead of the success of learning, while principal as central power in the development of quality culture. The role of teachers in creating the school culture has a great impact on the learning process.

4) It is necessary to improve various sources of excellence with training models to become an excellence school i.e. teacher professionalism, school culture, good organization network, and increased parental participation.

\section{REFERENCES}

[1] B. Sumintono, "Sekolah Unggulan;Pendekatan Pengembangan Kapasitas Sekolah”, vol. II, no. 1, pp. 1-19, 2013.
[2] L. Bell \& P. Kent, "The Cultural Jigsaw a Case Study The Ways in Which Sixth-Form Students Perceive School Culture", in Journal of the British Educational Leadership, Management \& Administration Society, vol. XVI, no. 2, pp. 38-44, 2010.

[3] Direktorat Pembinaan Sekolah Dasar, " Panduan Pembinaan Manajemen Berbasis Sekolah di Sekolah Dasar", Kemdikbud, 2013.

[4] A.Harris, "Building the Capacity for School Improvement",inSchool Leadership and Management, vol.XXI,no. 3,pp. 261-270, 2001.

[5] H. Jackson, "Effective Leadership for School Improvement", in New York : Routledge Falmer, 2003.

[6] Ihsan, Djailani AR, Sakdiah Ibrahim, "Manajemen Sekolah dalam Meningkatkan Mutu Pendidikan pada SD Negeri 62 Banda Aceh", inJurnal Administrasi Pendidikan Pascasarjana Universitas Syiah Kuala, vol. IV, no. 2, pp. $12-20,2014$.

[7] J. S. Arcaro, "Pendidikan Berbasis Mutu, PrinsipPrinsip Perumusan dan Tata Langkah Penerapanan”, Kemdikbud, 2007.

[8] Direktorat Pembinaan Sekolah Dasar, "Panduan Lomba Budaya Mutu di SD”, Kemdikbud, 2016.

[9] M. Nur, C. Z. Harun, Sakdiah Ibrahim, "Manajemen Sekolah dalam Meningkatkan Mutu Pendidikan pada SD Dayah Guci Kabupaten Pidie”, inJurnal Administrasi Pendidikan Pasca sarjana Universitas Syiah Kuala, vol IV, no. 1, pp. 93 103,2016.

[10] Macneil, J.A., Prater, D.L., \& Busch, S, “The Effects of School Culture and Climate on Student Achievement", inJournal Leadership in Education, vol. XII, no. 2,197-209, 2010.

[11] Macbeath, J. \& Mortimore, P,“Improving School Effectiveness", 2005.

[12] Morrison, D.M. \& Mokashi K. \& Cotter, K, "Instructional Quality Indicators: Research foundations", Cambridge University, 2011.

[13] Peraturan Pemerintah No.19 tahun 2005 aboutNational Education Standard

[14] Saiful Arif, "Budaya Belajar siswa pada Sekolah Unggul di SMA Negeri 1 Pamekasan", in Nuansa, Vol. VIII, no. 2, pp. 183-201, 2011

[15] S. B. Raharjo, "Manajemen Sekolah Untuk mencapai sekolah Unggul,; Studi Kasus di SMA Negeri I Sleman", inJurnal Pendidikan dan Kebudayaan, vol. I, no. 2, pp. 201-20172016.

[16] Siswanto,"Pengembangan Model Kultur Sekolah", in Jurnal Penelitian dan Evaluasi Pendidikan, vol. XVIII, no. 1, pp. 220-237, 2014.

[17] Supriyono, "Membentuk Kultur Pembelajaran yang Mendidik", inJurnal Paramita,vol. XXII no. 2, pp. 219-227, 2012.

[18] S. Darmiatun \&Daryanto, "Implementasi Pendidikan Karakter melalui Budaya Sekolah”, 2013. 